\title{
Utilización de polialcamida en cirugía reconstructiva y estética facial
}

\section{Use of polyalkylimide in facial reconstructive and cosmetic surgery}

\author{
M. Cuesta Gil', A. Valverde Carrasco 2 B. Duarte Ruiz , F. Riba García 3 , M. Castrillo Tambay3, \\ V. del Pino ${ }^{4}$
}

Resumen: Objetivos. Presentar nuestra experiencia en el manejo y aplicación de biomateriales no reabsorbibles (poliaquilamida) en pacientes con defectos faciales de diversa etiología.

Material y métodos. Empleamos poliaquilamida (Bio-Alcamid ${ }^{\circledR}$ ) en un total de catorce pacientes. Cuatro pacientes presentaban distintos grados de lipodistrofia facial secundaria a tratamientos antiretrovirales. Otros cuatro, consultaron porque deseaban mejorar el aspecto de su perfil labial. Tres pacientes habían sido sometidos con anterioridad a exéresis oncológicas, y otros dos mostraban defectos faciales derivados de traumatismos. Finalmente, un paciente presentaba un defecto nasal, secuela de una rinoplastia previa.

Resultados. Todos los pacientes mostraron un índice muy elevado de satisfacción. No se registraron complicaciones graves. Queremos señalar la estabilidad y durabilidad del implante.

Conclusiones. La seguridad y sencillez de esta técnica asociada al alto grado de satisfacción manifestado por los pacientes, animan al empleo de estas sustancias en la corrección de defectos faciales de diversa etiología.

Palabras clave: Biomateriales; Poliaquilamida; Lipodistrofia facial; Estética facial.

Recibido: 06.10 .06

Aceptado: 26.03 .07
1 Jefe de Servicio de Cirugía Oral y Maxilofacial. Hospital General de Ciudad Real, España.

2 Médico Residente. Servicio de Cirugía Plástica, Estética y Reparadora. Hospital de Alicante, España.

3 Médico Adjunto. Servicio de Cirugía Oral y Maxilofacial. Hospital General de Ciudad Real, España.

4 Cirujano Plástico. Práctica Privada. Madrid, España.

\section{Correspondencia:}

Matías Cuesta Gil

Pasaje de Lanzarote 6, Portal $2,3^{\circ} \mathrm{A}$.

13001 - Ciudad Real, España.

Email: matiasc@sescam.jccm.es
Abstract: Objectives. To report our experience with the management and application of nonresorbible biomaterials (polyalkylimide) in patients with facial defects of diverse origin.

Material and methods. Polyalkylimide (Bio-Alcamid ${ }^{\circledR}$ ) was used in fourteen patients. Four patients had different grades of facial lipodystrophy secondary to antiretroviral treatment. Four patients sought to improve their labial profile. Three patients had previously undergone oncological excision and two had traumatic facial defects. Finally, one patient had a nasal defect due to rhinoplasty.

Results. All patients were very satisfied. No serious complications occurred. Implants were stable and durable.

Conclusions. The safety and simplicity of this technique, and the high degree of patient satisfaction, encourage the use of these substances to correct facial defects of diverse etiology.

Key words: Biomaterials; Polyalkylimide; Facial lipodystrophy; Facial esthetics. 


\section{Introducción}

Desde mediados de los años noventa, los cirujanos que realizamos procedimientos quirúrgicos reconstructivos y estéticos, disponemos de materiales inyectables biocompatibles, ${ }^{9}$ que permiten otorgar relleno y/o volumen a regiones tan dispares como la cara o las mamas. A nivel facial, estos materiales se utilizan tanto en la cirugía reconstructiva (para relleno de defectos creados tras exéresis oncológicas o defectos postraumáticos), como en la estética (para relleno de labios, con el fin de aumentar la proyección de los mismos; surcos, etc.).

Sin duda alguna, las posibilidades que ofrecen este tipo de materiales son casi infinitas, estando condicionadas las aplicaciones terapéuticas de los mismos a sus componentes y características fisicoquímicas. ${ }^{13}$

El material de relleno por excelencia empleado en el cuerpo humano es el propio tejido adiposo del paciente..$^{14,15}$ De este modo, mediante técnicas de liposucción y centrifugado o decantación, esta grasa aspirada y tratada se puede inyectar nuevamente en determinadas áreas corporales que presenten algún defecto con el fin de lograr el relleno del mismo. Esta técnica, aparentemente idónea y biocompatible, presenta riesgo de pérdida del injerto con el paso del tiempo, así como desarrollo de necrosis grasa. ${ }^{7}$

Actualmente, existen una serie de materiales sintetizados artificialmente, que una vez inyectados en el lecho receptor inician de forma temprana su proceso de degradación. ${ }^{11}$ Son los denominados materiales transitorios o degradables, siendo su máximo representante el ácido hialurónico, cuyos efectos son apreciables durante seis-doce meses. Así mismo, disponemos de otro tipo de materiales, llamados permanentes, los cuales son capaces de perdurar durante mucho más tiempo en nuestro organismo, siendo por ello sus efectos claramente más duraderos. Se trata del polimetilmetacrilato (Artecoll ${ }^{\circledR}$ ) y la poliaquilamida (Bio-Alcamid ${ }^{\circledR}$ ). ${ }^{13}$

En este trabajo queremos reflejar nuestra pequeña experiencia con la polialcamida en el relleno de defectos faciales de diversas etiologías. De igual forma, nos gustaría animar a los lectores en el uso de este tipo de materiales dado sus buenos resultados, su fácil manejo y el bajo índice de complicaciones.

\section{Material y método}

Hemos empleado poliaquilamida (Bio-Alcamid ${ }^{\circledR}$ ) en un total de catorce pacientes, siendo las indicaciones que motivaron el empleo de esta sustancia, muy variadas. ${ }^{10}$

Cuatro pacientes presentaban distintos grados de lipodistrofia facial secundaria a tratamientos antiretrovirales (Casos 1 y 2 ) (Figs. 1-3). Otros cuatro, consultaron porque deseaban mejorar el aspecto de su perfil labial (Caso 3) (Fig. 4). Tres pacientes habían sido sometidos con anterioridad a exéresis oncológicas (Caso 5) (Fig. 6), y otros dos mostraban defectos faciales derivados de traumatismos. Finalmente, un paciente presentaba un defecto nasal, secuela de una rinoplastia previa (Caso 4) (Fig. 5).

Queremos destacar que la proyección del labio y su relación con el perfil de la cara marca de una forma muy plausible la estética facial

\section{Introduction}

Since the mid-1990s, surgeons who perform reconstructive and cosmetic surgical procedures have injectable biocompatible materials ${ }^{9}$ available for filling and/or adding volume to regions as varied as the face and breasts. These materials are used in the face in both reconstructive surgery (to repair defects due to oncological excision or trauma) and cosmetic surgery (to fill lips to increase their prominence, repair clefts, etc).

The possibilities of this type of material undoubtedly are almost unlimited, therapeutic applications being conditioned by their components and physical and chemical characteristics. $^{13}$

The ideal filler for use in the human body is the patient's own fatty tissue. ${ }^{14,15}$ Liposuction techniques, centrifugation and decanting are used to obtain the material. This aspirated and treated fat can then be reinjected into certain areas of the body with defects as a filler. This apparently ideal and biocompatible technique, however, carries the risk of graft loss, with time, and the development of fatty necrosis.7

At present, a series of artificially synthesized materials exist that begin to degrade soon after injection in the receptor bed. ${ }^{11}$ These materials are known as transitory or degradable materials, and their foremost representative is hyaluronic acid, which has effects that last for six to twelve months. Another type of materials, known as permanent biomaterials, last much longer in the body and their effects are more prolonged. These materials include polymethylmetacrylate (Artecoll ${ }^{\circledR}$ ) and polyalkylimide (Bio-Alcamid $\left.{ }^{\circledR}\right)^{13}$

In this article we report our small experience with polyalkylimide in filling facial defects of diverse origin. We would like to encourage readers to use such materials because of their good results, easy management, and low complication rate.

\section{Material and method}

We used polyalkylimide (Bio-Alcamid ${ }^{\circledR}$ ) in a total of fourteen patients with a variety of indications for the use of this substance. 10

Four patients had different degrees of facial lipodystrophy secondary to antiretroviral treatment (Cases 1 and 2). Four sought to improve their labial profile (Case 3). Three patients had previously undergone oncological excision (Case 5) and two had traumatic facial defects. Finally, one patient had a nasal defect due to rhinoplasty (Case 4).

We want to emphasize that the way the lip projects in relation to the facial profile conditions the facial esthetics of individuals. We used polyalkylimide for this purpose (eg, to improve labial projection) in three women in their forties and in a much younger man. More than twelve months after application of the nonresorbible biomaterial, the injectable endoprosthesis remained stable and the cosmetic result was 


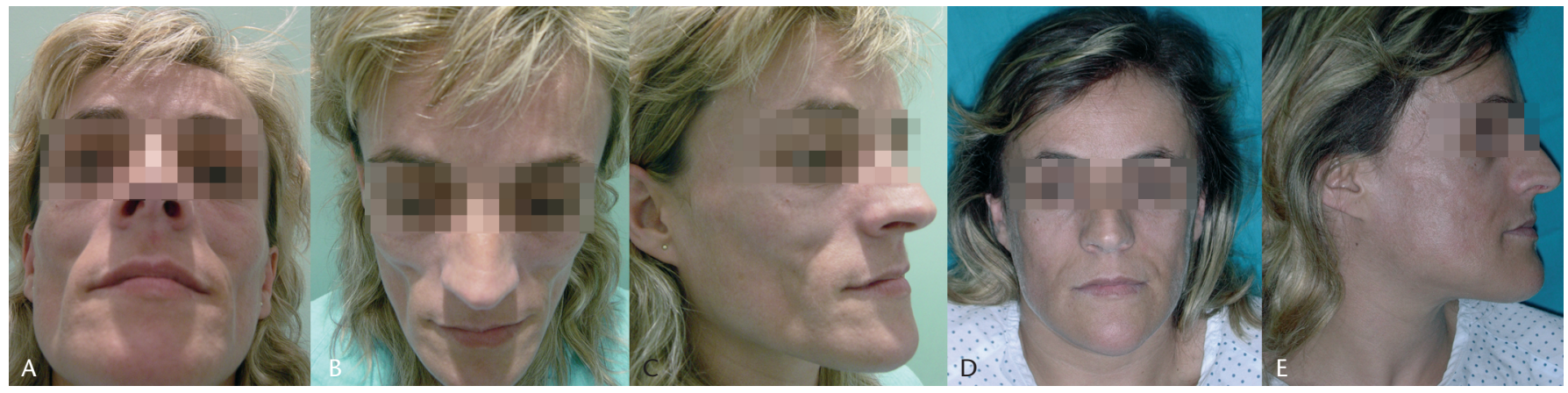

Figura 1. Caso 1. Lipodistrofia facial asociada a terapia antirretroviral. A) Preoperatorio. Visión superior. B) Preoperatorio. Visión lateral. C) Preoperatorio. Visión de frente en hiperextensión. D) Postoperatorio tardío (3 años). Visión de frente. E) Postoperatorio tardío (3 años). Visión lateral. Figure 1. Facial lipodystrophy associated with antiretroviral therapy. A) Before surgery. Upper view. B) Before surgery. Side view. C) Before surgery. Frontal view in hyperextension. D) Late postoperative period (3 years). Frontal view. E) Late postoperative period (3 years). Side view.

de los individuos. Nosotros, hemos utilizado poliaquilamida, como ya hemos indicado con anterioridad, en tres mujeres en su cuarta década de la vida, y en un varón mucho más joven, con el fin de alcanzar dicho objetivo (es decir, mejorar la proyección del labio). Transcurridos más de doce meses desde la aplicación del biomaterial no reabsorbible, la endoprótesis inyectable permanece estable, habiéndose logrado un resultado estético muy satisfactorio en todos los casos. ${ }^{12}$

A todos los pacientes se les realizó una historia clínica completa y se les informó tanto verbalmente como por escrito del tratamiento (en que consistía, complicaciones, riesgos derivados del mismo, etc.). Se instauró profilaxis antibiótica de amplio espectro $y$, utilizando un campo estéril, se aplicaron las agujas suministradas conjuntamente con el producto para la inyección del material de relleno en la hipodermis. En doce pacientes, el tratamiento se realizó bajo anestesia local (85\%) y todos ellos, excepto uno, se completaron en una sola sesión. ${ }^{3}$

Cuando el paciente presenta dudas acerca del volumen a implantar, es preferible realizar un primer tratamiento con material reabsorbible, anotando los milímetros de material inyectado en cada área. Al cabo de 8-10 meses se reevalúa al paciente y se coloca más o menos volumen de biomaterial permanente, según el resultado previo.

Tras la aplicación del producto, se realizaron masajes circulares sobre el lecho receptor y se recomendó el empleo de bolsas de hielo para lograr disminuir la inflamación.

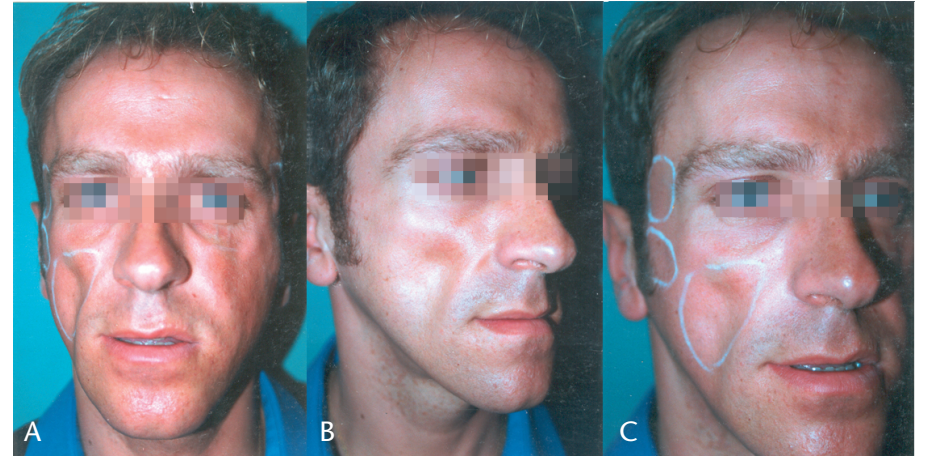

Figura 2. Caso 2. Lipodistrofia facial asociada a terapia antirretroviral. A) Preoperatorio. Visión de frente. B) Preoperatorio. Visión lateral. C) Preoperatorio. Visión lateral. Planificación del caso clínico.

Figure 2. Facial lipodystrophy associated with antiretroviral therapy. A) Before surgery. Frontal view. B) Before surgery. Side view. C) Before surgery. Side view. Planned intervention.

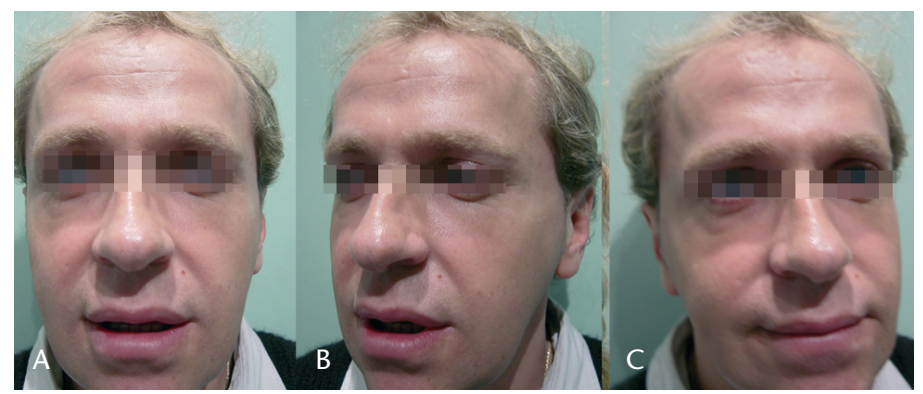

Figura 3. Caso 2. A) Postoperatorio tardío (5 años). Visión de frente. B) Postoperatorio tardío (5 años). Visión lateral. C) Postoperatorio tardío (5 años). Visión lateral.

Figure 3. Case 2. A) Late postoperative period (5 years). Side view. B) Late postoperative period (5 years). Side view. C) Late postoperative period (5 years). Side view.

very satisfactory in every case. ${ }^{12}$

A complete clinical history was obtained from all patients and they were informed verbally and in writing about the treatment (what it involved, complications and risks, etc). Broadspectrum antibiotic prophylaxis was begun and a sterile field was prepared. The needles supplied with the product were used to inject the filler in the hypodermis. The procedure was performed under local anesthesia (85\%) in twelve patients. Only one session was needed to complete the procedure in every patient except one. ${ }^{3}$

When the patient is not sure about how much volume he or she wants to have implanted, preliminary treatment with resorbible material is performed, recording the milliliters of material injected in each area. After 8-10 months, patients were reevaluated and the volume of permanent biomaterial injected was adjusted in accordance with the previous result.

After applying the product, the receptor bed was massaged circularly and ice packs were recommended to reduce inflammation. 


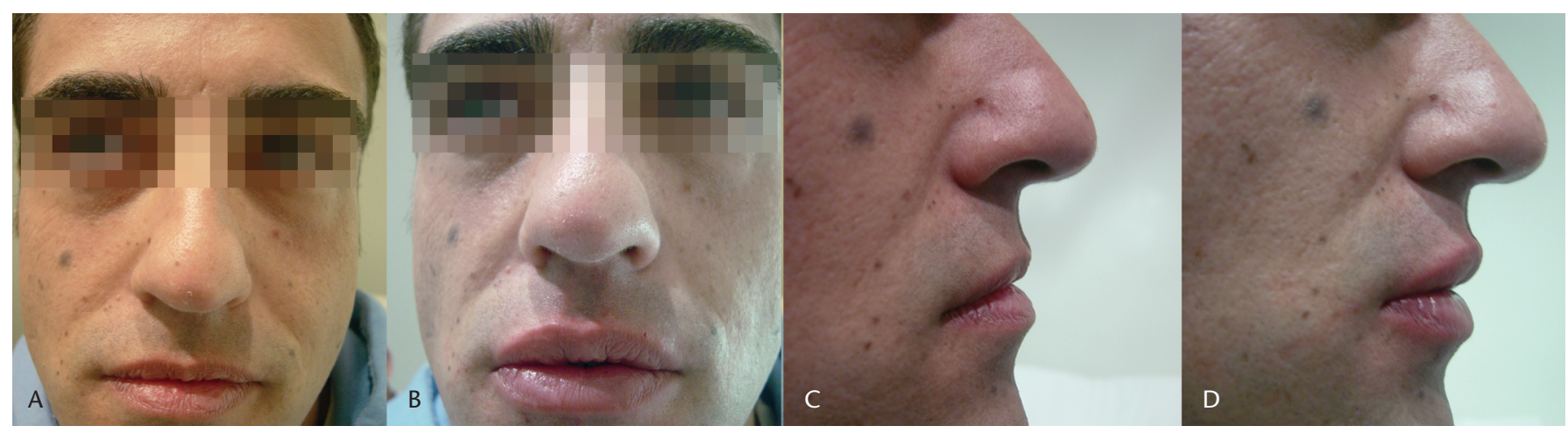

Figura 4. Caso 3. Hipoplasia labio superior. A) Preoperatorio. Visión de frente.B) Preoperatorio. Visión lateral. C) Postoperatorio inmediato. Visión lateral. D) Postoperatorio inmediato. Visión de frente.

Figure 4. Case 3. Upper lip hypoplasia. A) Before surgery. Frontal view.B) Before surgery. Side view. C) Immediate postoperative period. Side view. D) Immediate postoperative period. Frontal view.

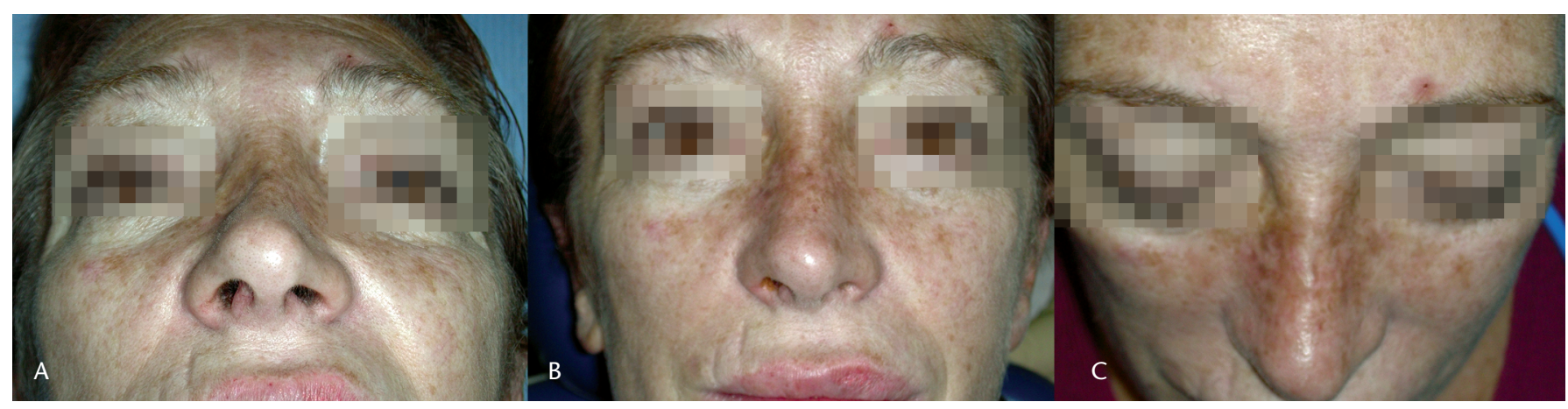

Figura 5. Caso 4. Secuela de rinoplastia. A) Postoperatorio inmediato. Visión superior. B) Secuela de tercera rinoplastia. Hundimiento lateral nasal. C) Postoperatorio inmediato. Visión de frente.

Figure 5. Case 4. Rhinoplasty sequela. A) Immediate postoperative period. Upper view. B) Sequela of third rhinoplasty. Lateral nasal collapse. C) Immediate postoperative period. Frontal view.

Destacar que ninguno de nuestros pacientes presentaba antecedentes de colagenosis, infección activa o radioterapia en la zona a tratar así como una diabetes mellitus no tratada que contraindicara la instauración del tratamiento. ${ }^{5}$

\section{Resultados}

Los catorce pacientes (100\%) calificaron de "muy satisfactorio" el resultado obtenido tras la inyección del biomaterial. Además, todos ellos destacaron el incremento y mejoría experimentado tanto en sus relaciones sociales como en su propia autoestima, desarrollado a partir del tratamiento con biopolímeros. La valoración del procedimiento por parte de los pacientes fue de "muy poco traumático y doloroso" en doce de ellos. Tan solo un paciente refirió "dolor importante y edema llamativo". Transcurridos más de doce meses desde la aplicación del biomaterial no reabsorbible, la endoprótesis inyectable permanece estable, habiéndose logrado un resultado estético muy satisfactorio en todos los casos. ${ }^{12}$ Finalmente indicar que no hemos registrado ninguna complicación en relación con la aplicación del biopolímero.
It should be noted that none of our patients had a history of collagenosis, active infection or radiotherapy in the treatment area, or untreated diabetes mellitus, which are contraindications for treatment. ${ }^{5}$

\section{Results}

The fourteen patients (100\%) characterized the result obtained after injecting the biomaterial as "very satisfactory". All of them claimed that their social relations and selfesteem had increased and improved as a result of biopolymer treatment.

Patients evaluated the procedure as "not very traumatic or painful" in twelve cases. Only one patient said that "it was painful and produced intense swelling". More than twelve months after application of the nonresorbible biomaterial, the injectable endoprosthesis remained stable and the cosmetic result was very satisfactory in every case. ${ }^{12}$ No complication related with use of the biopolymer was observed. 


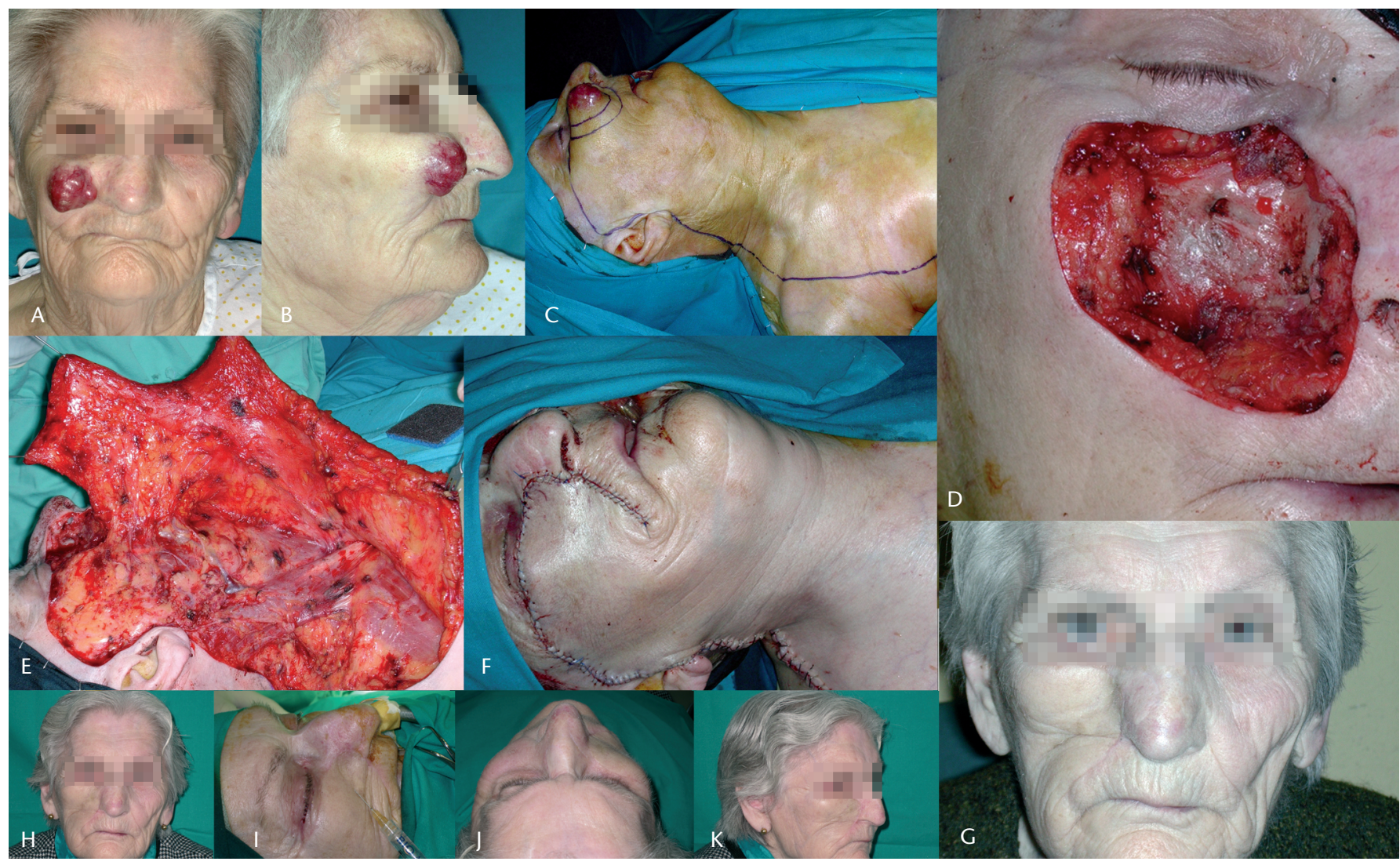

Figura 6. Caso 5. Secuela oncológica. A) Tumor de anejos cutáneos en mejilla derecha. Visión de frente. B) Tumor de anejos cutáneos en mejilla derecha. Visión lateral. C) Planificación quirúrgica. D) Visión intraoperatoria. Defecto tras exéresis oncológica. E) Visión intraoperatoria. Colgajo cervicopectoral para corrección del defecto oncológico. F) Reconstrucción inmediata del defecto oncológico con colgajo cervicopectoral. G) Postoperatorio $6^{\circ}$ mes con secuelas de ectropion y hundimiento de mejilla derecha. Visión de frente. H) Postoperatorio $2^{\circ}$ mes tras inyección de biomaterial de relleno. Visión de frente. I) Corrección del defecto mediante inyección de biomaterial de relleno. J-K) Resultado inmediato tras inyección de biomaterial de relleno. Visión superior.Figure 6. Case 5. Oncological sequela. A) Skin appendage tumor in right cheek. Frontal view. B) Skin appendage tumor in right cheek. Side view. C) Planned intervention. D) Intraoperative view. Defect left by oncological exeresis. E) Intraoperative view. Cervicopectoral flap for correction of oncological defect. F) Immediate reconstruction of oncological defect with cervicopectoral flap. G) Six months after surgery, ectropion and sunken right cheek sequelae are present. Frontal view. H) Six months after surgery, ectropion and sunken right cheek sequelae are present. Side view. I) Correction of defect by injection of biomaterial filler. J-K) Immediate result after injection of biomaterial filler. Upper view.

\section{Discusión}

El uso de materiales inyectables para corrección de defectos de cualquier índole no es tan reciente como podríamos suponer. Se remonta a los años 50 y 60, en Hong Kong, Japón y Taiwán, donde ya se utilizó parafina inyectada para aumentar el volumen mamario. Desafortunadamente, en la mayoría de los casos se desarrollaron reacciones a cuerpo extraño (parafinomas), que cursaron como masas indoloras en algunos pacientes, pero que en otros evolucionaron a úlceras que simulaban neoplasias mamarias.

Posteriormente, se comercializó la denominada "silicona líqui$\mathrm{da}^{\prime \prime}$, ampliamente utilizada en pacientes transexuales, creyéndose inicialmente que sintetizada en su forma pura por Dow Corning, minimizaba sus efectos adversos. 15

Actualmente, sabemos que la "silicona líquida" origina inflamaciones crónicas severas que en ocasiones requieren amplios desbridamientos quirúrgicos. También se han registrado casos de migración tisular del biomaterial, con resultado final de muerte por afectación de órganos vitales. Por estos motivos, la "silicona líqui-

\section{Discussion}

The injection of materials to correct defects of different sorts is not as recent as one might think. It dates back to the 1950s and 1960s, when paraffin was injected to increase breast volume in Hong Kong, Japan and Taiwan. Unfortunately, foreign body reactions developed (paraffinomas) in most cases. Some coursed as painless masses, but in other cases they led to the development of mammary ulcers that simulated neoplasms. So-called "liquid silicone" was later marketed and widely used in transsexual patients. Initially it was believed that use of the pure form of the product synthesized by Dow Corning would minimize adverse effects. ${ }^{15}$

We now know that "liquid silicone" causes severe chronic inflammation that sometimes requires extensive surgical debridement. Tissue migration of the biomaterial has been reported, ultimately resulting in death due to affectation of vital organs. For these reasons, "liquid silicone" is now prohibited by the FDA. ${ }^{14}$ 
da" está en la actualidad está terminantemente prohibida por la FDA. ${ }^{14}$

El Bio-Alcamid ${ }^{\circledast}$, es un gel polimérico gelatinoso cuyo componente principal es el agua (97\%) y que cuenta tan solo con un $3 \%$ de poliaquilamida. ${ }^{1}$ Es por ello que este material derivado de los acrílicos encuentra su principal indicación en la corrección de déficits de tejido blando. De este modo, una vez inyectado en la hipodermis, el implante se recubrirá con una fina capa de colágeno aislándose del resto de tejidos circundantes. ${ }^{4}$ Esta es la razón por la que se le suele denominar "endoprótesis inyectable". A diferencia de otras sustancias de relleno utilizadas años atrás y hoy prohibidas en nuestro país (como la silicona fluida o líquida), el Bio-Alcamid ${ }^{\circledR}$ es un material permanentemente estable, evitándose de este modo su migración tisular. ${ }^{6}$ Otra importante ventaja desarrollada por este compuesto es su radiotransparencia, lo que evita que se interfiera el resultado de determinadas pruebas diagnósticas.

El uso de materiales inyectables es hoy por hoy un procedimiento terapéutico habitual en la práctica diaria de los cirujanos que realizan tratamientos estéticos y reconstructivos. Con ellos conseguimos modificar de una manera rápida y eficaz el surco nasogeniano, el volumen labial, la proyección malar y los distintos surcos de expresión facial. Cada día es más frecuente también el empleo de BioAlcamid $^{\circledR}$ en procedimientos terapéuticos estéticos destinados a pacientes $\mathrm{VIH}$ positivos sometidos a tratamientos antiretrovirales, los cuales muestran signos evidentes y llamativos de lipodistrofia facial.2,8

El empleo de este tipo de implantes solo origina molestias leves, que remiten con analgésicos de primer escalón. Es frecuente la aparición de una ligera inflamación que desaparece pasadas 24-48 horas en la mayoría de casos. Las complicaciones graves son excepcionales y en ninguno de nuestros pacientes se presentaron.

Aunque los tratamientos realizados bajo una técnica correcta, son valorados como altamente satisfactorios tanto por el paciente como por el cirujano, los mayores problemas se asocian a la naturaleza intrínseca del implante. Como ya hemos dicho anteriormente, la poliaquilamida es un compuesto estable en el tiempo. Tanto es así, que se le considera un material permanente. De igual manera, hemos constatado la gran estabilidad y durabilidad de este implante, junto con la ausencia de migración del material, pero debemos recordar que todavía desconocemos las propiedades de este compuesto a largo plazo y por eso hay que esperar más tiempo para obtener conclusiones más definitivas.

Cuando realizamos un tratamiento con implantes inyectables debemos facilitar a los pacientes un consentimiento en el que les informamos, no solo de las propiedades de la poliaquilamida, sino también de la existencia y cualidades de los denominados materiales inyectables transitorios. Y es que el Bio-Alcamid ${ }^{\circledR}$ es una sustancia inyectable permanente; hecho que puede ser mal aceptado a largo plazo por nuestros pacientes. Es decir, es posible que un paciente años después de someterse a un tratamiento estético con el fin de proyectar su región malar, considere en ese momento de su vida excesiva la proyección que años atrás consideró agradable y satisfactoria. Debemos tener siempre en cuenta, que la retirada de estos materiales es en la mayoría de los casos muy difícil, incluso prácticamente imposible en algunas localizaciones como es el caso de los labios.
Bio-Alcamid ${ }^{\circledast}$ is a gelatinous polymeric gel consisting mainly of water (97\%) with only 3\% polyalkylimide. ${ }^{1}$ For this reason, the main indication of this acrylic-derived material is the correction of soft tissue defects. When the implant is injected in the hypodermis, it is coated by a fine layer of collagen that isolates it from the surrounding tissues. ${ }^{4}$ This is why it is often referred to as an "injectable endoprosthesis". Unlike other fillers used years ago and now prohibited in Spain (eg, fluid or liquid silicone), Bio-Alcamid is a permanently stable material, which prevents tissue migration. 6 Another important advantage of this compound is its radiotransparency, so it does not interfere with the result of certain diagnostic tests.

Injectable materials are now used routinely in therapeutic procedures by surgeons who perform cosmetic and reconstructive surgery. This material makes it possible to quickly and effectively modify the nasogenial furrow, lip volume, malar prominences, and facial expression wrinkles. The use of Bio-Alcamid is increasingly common in cosmetic therapeutic procedures for HIV-positive patients receiving antiretroviral treatment who exhibit marked signs of facial lipodystrophy. 2,8

The use of this type of implants originates only mild discomfort, which can be relieved with first-line analgesics. Mild inflammation is frequent and disappears within 24-48 hours in most cases. Serious complications are exceptional and did not occur in any of our patients.

Interventions performed with proper technique are considered highly satisfactory by both patient and surgeon, the most important problems arising from the intrinsic nature of the implants. Polyalkylimide, as mentioned above, is a stable compound. This is why it is considered a permanent material. We have observed the stability and durability of this implant, together with the absence of migration of the material. However, we still do not know the long-term properties of this compound and until we have long-term results, no definitive conclusions can be drawn.

When we perform a procedure with injectable implants, patients must given their consent after being informed about the properties of polyalkylimide, as well as the existence of the so-called transitory injectable materials and their properties. Bio-Alcamid ${ }^{\otimes}$ is a permanent injectable substance that may have long-term results that are unacceptable to patients. For instance, years after undergoing a cosmetic intervention to enhance the malar region, the patient may eventually view the prominence that was once considered attractive and satisfactory as excessive. We must always remember that removal of these materials is difficult in most cases, and even almost impossible in some locations, like the lips.

The general guideline for direct use of nonresorbible material is to inject moderate volumes. After 4-5 weeks, we reevaluate the patient. If the result is insufficient, we can perform a new biopolymer injection. However, if the volume injected is excessive, it is complicated to remove the material and complications often develop. 
Como norma general, cuando utilizamos directamente materiales no reabsorbibles, preferimos inyectar volúmenes moderados. Al cabo de 4-5 semanas, reevaluamos al paciente, de tal manera que si el resultado alcanzado es insuficiente, podemos realizar una nueva inyección de biopolímero. Sin embargo, si nos excedemos en el volumen aplicado, la retirada del material es muy compleja y el desarrollo de complicaciones frecuente.

\section{Conclusiones}

1. La utilización de materiales inyectables con fines estéticos se realiza siempre bajo anestesia local. Este tipo de correcciones estéticas las podemos tipificar como "a la carta", ya que será el paciente el que elija la durabilidad del implante al que se va a someter, así como la región a intervenir, todo ello consensuado con las recomendaciones del cirujano que lo va a realizar.

2. Los materiales empleados son altamente estables y su adaptabilidad a la zona receptora es excelente, al igual que su tacto. Su biocompatibilidad y relación con los tejidos circundantes evita la posibilidad de que se desencadene una reacción alérgica al implante.

3. Debido a la naturaleza intrínseca de los materiales inyectables permanentes debemos evitar la sobrecorrección, que en ocasiones y cuando manejamos inyectables transitorios puede ser demandada por nuestros pacientes con el fin de acentuar los resultados derivados del tratamiento.

4. En general el resultado conseguido es valorado como altamente satisfactorio por los pacientes. El tacto logrado y el aspecto alcanzado tras el tratamiento son considerados naturales siempre y cuando la técnica aplicada sea la correcta.

\section{Bibliografía}

1. Terenzi V, Leonardi A, Covelli E, Buonaccorsi S, Indrizzi E, Fenicia V,Perdicchi A, Fini G. Parry-Romberg syndrome. Plast Reconstr Surg 2005;116:97e-102e.

2. Burnouf $M$, Buffet $M$, Schwarzinger $M$, Roman $P$, Bui P, Prevot $M$, Deleuze J, Morini JP, Franck N, Gorin I, Dupin N. Evaluation of Coleman lipostructure for treatment of facial lipoatrophy in patients with human immunodeficiency virus and parameters associated with the efficiency of this technique. Arch Dermatol 2005; 141:1220-4.

3. Orenstein A, Bar-Meir E. Bio-alkamid: avoiding the leak. Plast Reconstr Surg 2005;115:1789-90.

4. Ramires PA, Miccoli MA, Panzarini E, Dini L, Protopapa C. In vitro and in vivo biocompatibility evaluation of a polyalkylimide hydrogel for soft tissue augmentation. J Biomed Mater Res B Appl Biomater 2005;72:230-8.

5. Claoue BL, Rabineau P. The polyalkylimide gel: experience with Bio-Alcamid. Semin Cutan Med Surg 2004;23:236-40.

6. Formigli L, Zecchi S, Protopapa C, Caporale D, Cammarota N, Lotti TM. BioAlcamid: an electron microscopic study after skin implantation. Plast Reconstr Surg $2004 ; 113: 1104-6$.

7. Mojallal A, Foyatier JL. The effect of different factors on the survival of transplanted adipocytes. Ann Chir Plast Esthet 2004;49:426-36.

8. Protopapa C, Sito G, Caporale D, Cammarota N. Bio-Alcamid in drug-induced lipodystrophy. J Cosmet Laser Ther 2003;5:226-30.

\section{Conclusions}

1. Injectable materials used for cosmetic purposes are always administered under local anesthesia. This type of cosmetic corrections can be characterized as "a la carte" because the patient will choose the durability of the implant to be used, in addition to the region to be remodeled, with the surgeon who will perform the procedure.

2. The materials used are highly stable and their adaptability to the receptor area and texture are excellent. Their biocompatibility and relation with the surrounding tissues eliminates the possibility of triggering allergic reactions to the implant.

3. Due to the nature of permanent injectable materials, we must avoid the sort of overcorrection that is sometimes demanded by patients to accentuate treatment results when using transitory injectables.

4. Generally speaking, the result obtained is considered highly satisfactory by patients. The texture and appearance achieved are considered natural as long as proper technique is used. 
9. Pacini S, Ruggiero M, Cammarota N, Protopapa C, Gulisano M. BioAlcamid, a novel prosthetic polymer, does not interfere with morphological and functional characteristics of human skin fibroblasts. Plast Reconstr Surg 2003;111:489-91.

10. Pacini S, Ruggiero M, Morucci G, Cammarota N, Protopapa C, Gulisano M. Bio-alcamid: a novelty for reconstructive and cosmetic surgery. Ital J Anat Embryol 2002;107:209-14.

11. Bergeret-Galley $C$, Latouche $X$, Illouz YG. The value of a new filler material in corrective and cosmetic surgery: DermaLive and DermaDeep. Aesthetic Plast Surg 2001;25:245-9.
12. Alster TS, West TB. Human-derived and new synthetic injectable materials for soft-tissue augmentation: Current status and role in cosmetic surgery. Plast Reconstr Surg 2000;105:2515-20.

13. Klein AW, Elson ML. The history of substances for soft tissue augmentation. Dermatol Surg 2000;26:1096-9.

14. Spira M. Failure to remove soft tissue injected with liquid silicone without the use of suction and honesty in scientific medical reports. Plast Reconstr Surg 2000;105:1909-14.

15. Rudolph CM, Soyer HP, Shuller-Petrovic S, Kerl H. Foreign body granulomas due to injectable aesthetic microimplants. Am / Surg Pathol 1999;23:113-8. 